where Ron collected at least four new butterfly species for Saskatchewan and two for Alberta. Once, on a flight to Lake Athabasca, refueling at La Ronge, Ron sneaked quickly along the runway, collecting with his foldable butterfly net.

Ron died in Tijuana, Mexico, on 2 December 2010 while seeking alternative cancer treatment. His wake and funeral were both held in the Standing Buffalo First Nation school gymnasium on the reserve near Fort Qu'Appelle. Twenty-five members of his aboriginal congregation followed the hearse on the long trip north to interment and graveside service at St. Andrew's Cemetery, north of Carragana, where he was interred near his twin brother, Don, who had died on 19 June 1993. Ron is survived by his wife, Barbara, son John and daughter Esther, all at Fort Qu'Appelle, and his son David (Vicki) Hooper and their family Alicia and Jesse in the United Arab Emirates.

Rev. Ron Hooper was Saskatchewan's last self-taught, all-round naturalist, a special and unique individual. His immense knowledge will be greatly missed.

\title{
IN MEMORIAM: JAMES A. SLIMMON, 1916-2010
}

\section{Stuart Houston}

\section{University Drive, Saskatoon SK S7N 0J8}

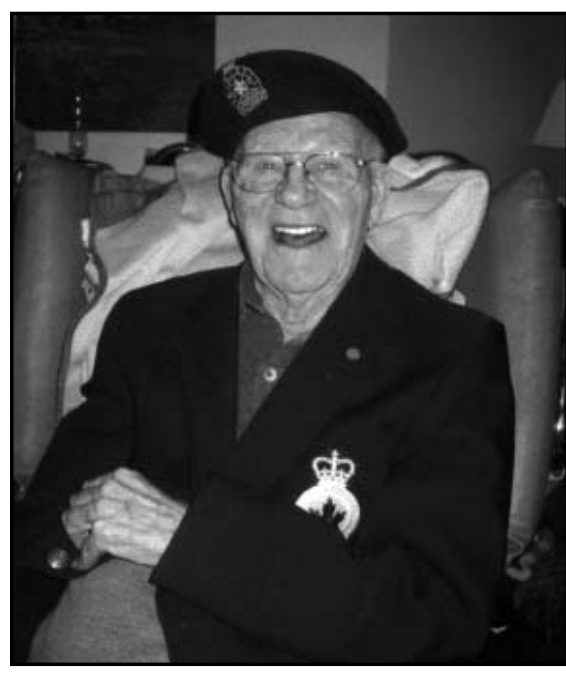

Jim Slimmon was born at Oak Lake, Manitoba, on 5 April 1916, the third of five children born to Gladstone and Maude Slimmon. At Neepawa High School, he was president of the student body. Jim enrolled in the Royal Canadian Air Force at the onset of World War II, was shot down over occupied Europe, and spent a year as a prisoner of war. After discharge, he was employed by Manitoba Co-op Wholesale in Winnipeg and married Vivian Fenson on 22 December 1945. When Federated Co-operatives Limited was formed in 1955, Jim was transferred to Saskatoon. He chose not to accept offered promotions in order to continue community service, and retired from Federated in 1981.

In the Saskatoon Natural History Society (now the Saskatoon Nature Society), Jim was a Director in 1963, Vice-President in 1964, President in 1965 and 1966, and Past-President in 1967. He returned to the board and served from 1986 to 1990.

At the provincial level, Jim was recording secretary of the Saskatchewan Natural History Society (SNHS) from 1964 to 1965; chair of the constitution committee (1966-1968); Newsletter editor (1965- 
1971); treasurer (1982-1984), and chair of the Finance Committee (1984-1989). In The Isabel Priestly Legacy (1996), Margaret Belcher stated, "No one on the Board was in a better position to understand the workings of the society. Perhaps no single member of the board was more valuable to the Society over the years. Slimmon's Finance Committee with its continuing preoccupations was more active than the Executive Committee" (footnote 106, p. 274 ). Belcher also wrote that "Slimmon's business acumen and long experience of the Society's affairs were of vital importance in dealing with the increasingly complex business of the Society. Under Slimmon's direction, the finance committee became truly accountable to the Board, presenting a financial report at each meeting" (p. 217). Slimmon "continued to be the Society's anchor in the sometimes turbulent waters of its operations. In 1988-89, he and his committee pursued the task they had earlier set of formulating policies to guide these operations. As these new guidelines were approved by the Board, they became part of the Society's formal policy manual"(p. 233).

Jim obtained a bird banding subpermit in 1962 and a master banding permit in 1981; specializing in blackbirds, he placed bands on 4357 yellow-headed and 2738 red-winged blackbirds. With the realization that there were major gaps in the knowledge of breeding birds within the Saskatoon Bird Area, Jim obtained a federal bird egg collecting permit in 1963. That year, he added 14 new species to the area list of breeding species. Jim was in the second group named as Fellows of the SNHS in 1988, along with Fred Bard, Bob Nero, and Jim and Shirley Jowsey.
Apart from his birding activity, Jim served tirelessly in his community and province. He was a district commissioner and member of the national training team in Boy Scouts Canada. He served as president or chair of the Community Health Service Association, Saskatchewan Health Care Association, Community Health Unit Board, Saskatoon Area Ambulance District, Saskatoon Animal Control Committee, and Vice-Chair of the City Hospital Board of Governors. He received the Meewasin Conservation Award in 1989. In 2005, he received a Centennial Medal for his lifetime of community service. Slimmon Road and its offshoot, Slimmon Place, have been named in his honour. They are immediately adjacent to the preserved waterbodies in southeast Saskatoon, appropriately saved following the Saskatoon Nature Society's representations to the city.

Jim suffered a heart attack 9 November 1996; anti-clotting medication was given, followed by a massive cerebral hemorrhage the next day. He spent the remainder of his life in the care of the Saskatoon Veterans Home and later, Sherbrooke Veterans Village. He donated his extensive bird's egg collection to the Biology Museum at the University of Saskatchewan. Jim is survived by his wife of 65 years, sons Doug and John, and daughters Judy and Kim, six grandchildren, their spouses, and five great-grandchildren.

\section{Acknowledgements}

Jim's widow, Vivian, provided additional details concerning his community service. J. Frank Roy improved the memorial. 